\title{
Adjudicating the Intersection of Marital Immigration, Domestic Violence, and Spousal Murder: China-Taiwan Marriages and Competing Legal Domains
}

\section{Sara L. Friedman}

Indiana University, slfriedm@indiana.edu

Follow this and additional works at: https://www.repository.law.indiana.edu/ijgls

Part of the Comparative and Foreign Law Commons, Family Law Commons, Immigration Law Commons, and the International Law Commons

\section{Recommended Citation}

Friedman, Sara L. (2012) "Adjudicating the Intersection of Marital Immigration, Domestic Violence, and Spousal Murder: China-Taiwan Marriages and Competing Legal Domains," Indiana Journal of Global Legal Studies: Vol. 19 : Iss. 1 , Article 9.

Available at: https://www.repository.law.indiana.edu/ijgls/vol19/iss1/9

This Symposium is brought to you for free and open access by the Law School Journals at Digital Repository @ Maurer Law. It has been accepted for inclusion in Indiana Journal of Global Legal Studies by an authorized editor of Digital Repository @ Maurer Law. For more information, please contact rvaughan@indiana.edu.

\section{$\Psi$}

JEROME HALL LAW LIBRARY

INDIANA UNIVERSITY

Maurer School of Law
Blooming ton 


\title{
Adjudicating the Intersection of Marital Immigration, Domestic Violence, and Spousal Murder: China-Taiwan Marriages and Competing Legal Domains
}

\author{
SARA L. FRIEDMAN*
}

\begin{abstract}
Cross-border marriages and other forms of family reunification dominate officially recognized migratory flows around the world today, and they offer the most widely recognized path to naturalized citizenship in destination countries. At the same time, however, transnational marriages may also rest on shaky foundations precisely because immigrant spouses depend on their citizen partner for legal status. When marriages fail due to domestic violence, they expose the incompatibility of different legal domains organized around domestic violence prevention and immigration regulation. This Article examines the legal conflicts that emerged in response to a recent case in Taiwan involving an immigrant wife from Mainland China who, after suffering several years of domestic violence, killed her citizen husband in 2006. The case underscores the complex and often unpredictable intersections of domestic violence prevention law, immigration policy, and feminist legal
\end{abstract}

* Associate Professor of Anthropology and Gender Studies, Indiana University. This article is based on twenty months of nonconsecutive ethnographic fieldwork conducted by the author in Taiwan and China between 2003 and 2011. Research support came from the National Science Foundation (\#BCS-0612679), the Wenner-Gren Foundation for Anthropological Research, and the Chiang Ching-kuo Foundation for International Scholarly Exchange. I thank Fred Aman for inviting me to participate in the Maurer School of Law's 2011 Globalization and Migration conference and the conference participants for their helpful feedback. Chao-ju Chen and Deborah Widiss provided invaluable comments and corrections that have made this a much stronger article. Shengzhi Li's astute research assistance helped me navigate the complex world of U.S. immigration policy. My greatest debt is to the many people in Taiwan who offered guidance and assistance with my study of domestic violence, especially Lai Fang-yu, Chen Mei-xing, Lin Meng-huan, Chen Yi-chien, Wang Hai-ling, Antonia Chao, Chen Hung-ying, Chang Fan-ju, and, of course, Zhao Yanbing herself. Unless otherwise noted, all translations are my own.

Indiana Journal of Global Legal Studies Vol. 19 \#1 (Winter 2012)

(C) Indiana University Maurer School of Law 
reforms aimed at women's empowerment. Despite the district-level court's unprecedented ruling of legitimate defense, the case continued to serve as a flashpoint for competing ethical orientations as it made its way through the appeals process, in turn exposing conflicting legal principles and gendered family role expectations faced by immigrant as opposed to citizen women. Although the initial ruling pointed to growing judicial recognition of the deep-seated psychological and emotional effects of domestic violence, its overall impact was undercut by the defendant's immigrant status and pervasive suspicions about marital motives triggered by that status. By analyzing the case itself and the various legal and activist strategies mobilized around it, this Article evaluates the limitations and possibilities of law and policy reforms enacted on the uneven terrain of domestic violence prevention and gendered immigration flows.

\section{INTRODUCTION}

During the Chinese New Year holiday in February 2006, Zhao Yanbing, a fifty-three-year-old immigrant wife from Mainland China, killed her elderly citizen husband, Jia Xinmin, in a housing compound for single, retired veterans in a central district of Taiwan's capital, Taipei. By Zhao's recounting, she had not eaten in four days and had been in great physical pain from an infected catheter, so she had asked her husband to take her to the hospital. When he refused, she requested he give her money so that she could go herself, at which point he picked up a cleaver and threatened to chop off her head were she to mention money again, a threat he had made in the past. Panicked, Zhao grabbed a hammer lying nearby and hit Jia over the head, presumably knocking him unconscious. Then she seized the knife from his hand and stabbed him repeatedly in the face and neck, killing him on the spot. After washing the knife in the kitchen sink, she walked to the nearby police station and turned herself in.

The murder and its legal aftermath have attracted much attention over the years from Taiwan's media, government, legal and social work professionals, and feminist and immigrant rights activists. As a sensationalist tale of domestic violence and spousal murder, however, the case could only travel so far. What drew the case into the spotlight and sustained interest over time was the way it wove together immigration and domestic violence through the tragedy of a marriage that was itself the legacy of long-lasting Cold War tensions and more than half a century of unresolved conflict between China and Taiwan. Such a violent end to the marriage was not preordained from the start, but it became more likely as interpersonal conflicts were refracted 
through the lens of ideological hostilities (a perspective inculcated in Jia Xinmin through years of military service) and as Zhao's vulnerable immigration status prevented her from envisioning a viable path out of an abusive marriage. Despite Taiwan's implementation of a national domestic violence prevention law in 1998 and Zhao's success in obtaining two court-issued protection orders prior to the murder, she could not leave the marriage altogether without jeopardizing her immigration status in Taiwan. ${ }^{1}$ And so she stayed, even with the abuse and her own declining physical and mental health, because she could not remain legally in Taiwan if she divorced and could not imagine a face-saving way to return to China.

This case shows how shattered migration dreams often result from a breakdown in intimate ties, especially when those bonds constitute the basis for legal immigration status. Cross-border marriages and other forms of family reunification dominate officially recognized migratory flows around the world today, and they offer the most widely recognized path to naturalized citizenship in destination countries. At the same time, however, transnational marriages may also rest on shaky foundations precisely because in most countries immigrant spouses face a period of conditional status during which their legal standing is tied to their marriage. An immigrant's dependent relationship to the citizenspouse during this vulnerable period generates tensions that can easily lead to marital conflict and failed migration trajectories. As in the case analyzed here, these migration failures underscore the incompatibility of different legal domains brought together in response to immigrant spouses who face intersecting systems of inequality based on gender, kinship, and nationality.

Zhao Yanbing experienced firsthand the difficulties of reconciling Taiwan's legal and judicial provisions established in the name of domestic violence prevention with immigration policies that police new paths to national inclusion forged through marriage to a citizen. Her husband's violent treatment brought these competing legal domains into sharp focus precisely because his abuse threatened the very relationship that undergirded her legal standing in Taiwan and justified her eligibility for naturalized citizenship in a country that provided few such avenues to legal inclusion. Moreover, Zhao's case shows that it is not merely the procedural and doctrinal features of these legal domains

1. Jiating Baoli Fangzhi Fa (家庭暴力防治法) [Domestic Violence Prevention Act] (promulgated by the Executive Yuan June 28, 1998, effective June 28, 1998) (Taiwan). This law made Taiwan the first country in East Asia to pass national legislation criminalizing domestic violence (defined as physical, psychological, and verbal abuse) and establishing a system of court-issued protection orders and social service networks to support those who suffered abuse. 
that prove difficult to reconcile, but also their divergent ethical orientations that reveal conflicting legal principles and gendered family role expectations faced by immigrant women as opposed to their citizen counterparts.

Comparative scholarship on immigration and family reunification has shown how immigration laws and policies remain a bastion of exclusion and inequality in liberal democratic countries ostensibly devoted to inclusion and equality. Whether in comparison to nationality and naturalization laws or domestic divorce and child custody laws, immigration laws are more likely to uphold traditional expectations for gender and family roles and to deploy them as tools for exclusion and the denial of family reunification claims. ${ }^{2}$ At the same time, this work also reveals that when ostensibly egalitarian or feminist-minded standards for adjudicating family-based claims are imported from domestic law into immigration policy, they may produce unintended consequences for immigrant women by establishing standards of intimacy and parental responsibility or care that are difficult for immigrants to achieve or prove. ${ }^{3}$ Simply introducing gender-neutral language into immigration and naturalization laws fails to resolve these tensions, for, as Chao-ju Chen argues, gender-neutral laws are not necessarily gender egalitarian in practice. ${ }^{4}$

2. See generally Jacqueline Bhabha, The "Mere Fortuity of Birth"? Children, Mothers, Borders, and the Meaning of Citizenship, in MIGRATIONS AND MOBILITIES: CITIZENSHIP, BORDERS, AND GENDER 187 (Seyla Benhabib \& Judith Resnik eds., 2009) (comparing nationality and naturalization laws to immigration laws); Catherine Dauvergne, Globalizing Fragmentation: New Pressures on Women Caught in the Immigration LawCitizenship Law Dichotomy, in MIGRATIONS AND MOBILITIES: CITIZENSHIP, BORDERS, AND GENDER 333 (Seyla Benhabib \& Judith Resnik eds., 2009) (examining global trends with respect to immigration law and barriers to legal citizenship); Sarah K. van Walsum, Transnational Mothering, National Immigration Policy, and European Law: The Experience of the Netherlands, in MigRATIONS AND MoBILITIES: CITIZENSHIP, BORDERS, AND GENDER 228 (Seyla Benhabib \& Judith Resnik eds., 2009) (examining the relationship between Dutch immigration laws and child custody); Janet Calvo, A Decade of SpouseBased Immigration Laws: Coverture's Diminishment, but Not Its Demise, 24 N. ILL. U. L. REv. 153 (2004) (describing this phenomenon as "the legacies of coverture" when discussing United States immigration law); Chao-ju Chen, Gendered Borders: The Historical Formation of Women's Nationality Under Law in Taiwan, 17 PosiTIONS 289 (2009) (comparing Taiwanese nationality and naturalization laws to immigration laws); Sara L. Friedman, Marital Immigration and Graduated Citizenship: Post-Naturalization Restrictions on Mainland Chinese Spouses in Taiwan, 83 PAC. AFF. 73 (2010) (examining Taiwanese immigration law with respect to Chinese spouses).

3. See van Walsum, supra note 2, at 229.

4. Chen, supra note 2, at 290. For discussions of how the term "immigrant" is an intersectional identity in its own right that exacerbates the vulnerability of domestic violence situations, see generally Edna Erez et al., Intersections of Immigration and Domestic Violence: Voices of Battered Immigrant Women, 4 FEMINIST CRIMINOLOGY 32 
This body of scholarship powerfully underscores the complexities of reconciling conflicting legal domains when principles that empower citizen women may work to the detriment of immigrant women or when legal frameworks for family and parental rights long established in domestic law confront protectionist rhetoric about border control and threats to the imagined integrity of national populations. Primarily based on research in western Europe and North America, this literature generally assumes a unidirectional flow of progressive legal and judicial reform that incorporates advances in domestic law into immigration law, while making adjustments in places to meet the specific needs of immigrants.

My discussion below reveals a more dynamic and contested process of both legal conflict and possible reconciliation, although it remains cautious about the potential for equalizing treatment of citizen and immigrant women in a context rife with suspicion about immigrant spouses' marital motives and, hence, their immigration goals. When Chinese wives find themselves caught between the conflicting demands of domestic violence prevention law and immigration policy, they experience firsthand the gaps between Taiwan's commitment to women's security and well-being, on the one hand, and the country's intense anxiety about immigrants from China and the "authenticity" of cross-Strait marriages, on the other. Faced with spousal abuse, many Chinese women feel trapped by an immigration regime that emphasizes border regulation and national security over individual rights to physical, emotional, and psychological safety.

Abused immigrant spouses encounter what I term a "double authenticity bind" because they must prove the legitimacy of both their marriage and their reasons for leaving the relationship if they are to retain legal status in Taiwan. Taiwan is not alone in policing marital fraud among cross-border couples or in demanding proof of domestic violence from immigrant spouses who seek to end an abusive marriage without jeopardizing their legal standing in the country. United States' policies, which often serve as a referent for both policymakers and activists in Taiwan, also display a similar tension between permitting vulnerable immigrant spouses to leave an abusive relationship and requiring them to prove both the abuse and a "good faith" marriage. With the 1986 Immigration Marriage Fraud Amendments, the United States instituted a conditional permanent residence status for immigrant spouses whose marriage to a U.S. citizen was shorter than two years in duration, thereby granting the citizen-spouse considerable

(2009); Cecilia Menjívar \& Olivia Salcido, Immigrant Women and Domestic Violence: Common Experiences in Different Countries, 16 GENDER \& SOC'Y 898 (2002). 
power over the immigrant-spouse's legal status in the country prior to removal of the residency conditions. ${ }^{5}$ Although the original amendments and subsequent revisions included waivers that potentially aided battered spouses, such waivers required burdens of proof that were virtually impossible for immigrant spouses to meet, as many lacked the language skills and social and economic resources to compile the necessary evidence. ${ }^{6}$

It was not until 1994, with passage of the first Violence Against Women Act (VAWA), that Congress allowed all battered spouses of U.S. citizens and legal permanent residents to self-petition for permanent residency. ${ }^{7}$ Evidentiary requirements for VAWA petitions remained quite high, however, and only with revisions in 1996, 2000, and 2005 were the protections offered by VAWA made accessible to most immigrant spouses, although petitioning remains a difficult and risky process. ${ }^{8}$ At the same time, new restrictions on immigrants' access to public benefits introduced as part of welfare and immigration reforms limited the efficacy of VAWA by restricting battered spouses' access to

5. Hiroshi Motomura, The Curious Evolution of Immigration Law: Procedural Surrogates for Substantive Constitutional Rights, 92 CoLUM. L. REV. 1625, 1659-60 (1992).

6. Felicia E. Franco, Unconditional Safety for Conditional Immigrant Women, 11 BERKELEY WoMEN's L.J. 99, 114 (1996); see also Michelle J. Anderson, A License To Abuse: The Impact of Conditional Status on Female Immigrants, 102 YALE L.J. 1401, 1417-18 (1993) (examining how language barriers create economic and psychological dependence for victims of abuse); Janet M. Calvo, Spouse-Based Immigration Laws: The Legacies of Coverture, 28 SAN DIEgo L. REV. 593, 630 (1991); Leslye E. Orloff \& Janice V. Kaguyutan, Offering a Helping Hand: Legal Protections for Battered Immigrant Women: A History of Legislative Responses, 10 AM. U. J. GENDER Soc. POL'Y \& L. 95, 116 (2002).

7. Violence Against Women Act of 1994, Pub. L. No. 103-322, 108 Stat. 1941-42 (1994).

8. See, e.g., Indira K. Balram, The Evolving, Yet Still Inadequate, Legal Protections Afforded Battered Immigrant Women, 5 U. MD. L.J. RACE, RELIGION, GENDER \& CLASS 387, 405 (2005) (citing the VAWA II evidentiary expansion to "any credible evidence relevant to the petition"); Calvo, supra note 2, at 183-87 (discussing the removal of obstacles in 2000); see generally Linda Kelly, Stories From the Front: Seeking Refuge for Battered Immigrants in the Violence Against Women Act, 92 Nw. U. L. REV. 665 (1998) (discussing the history of and problems resulting from VAWA); Deanna Kwong, Removing Barriers for Battered Immigrant Women: A Comparison of Immigrant Protections Under VAWA I \& II, 17 BERKELEY WOMEN's L.J. 137 (2002) (comparing the Violence Against Women Act [VAWA I] of 1994 with the Violence Against Women Act [VAWA II] of 2000); Orloff \& Kaguyutan, supra note 6, at 145-52 (reviewing VAWA II's easing of requirements and the expansion of categories); Katerina Shaw, Barriers to Freedom: Continued Failure of U.S. Immigration Laws to Offer Equal Protection to Immigrant Battered Women, 15 CARDOZO J. L. \& GENDER 663, 674-78 (2009) (reviewing current evidentiary burdens); Sarah M. Wood, VAWA's Unfinished Business: The Immigrant Women Who Fall Through the Cracks, 11 DUKE J. GENDER L. \& POL'Y 141 (2004) (reviewing the 1996 and 2000 revisions). 
much-needed economic support and legal aid. 9 These restrictions, together with delayed implementation and promulgation of recent VAWA statutes, have diminished some of VAWA's potential, although VAWA protections still offer critical support to immigrant spouses who seek to leave abusive marriages.

When compared with the United States, the situation for abused immigrant spouses in Taiwan is more restrictive, precisely because, at present, there are very few legal avenues available for immigrant spouses to leave an abusive marriage without facing deportation, and all such avenues require that the immigrant spouse is also the parent of a Taiwanese child. ${ }^{10}$ Moreover, Chinese spouses in particular face intense suspicion of their marital motives that derives from contested political ties between Taiwan and China and from assumptions that Chinese immigrants' economic motivations outweigh their commitment to the marriage itself. This climate of suspicion makes it difficult for social workers and immigration and legal activists in Taiwan, many of whom recognize the obstacles erected by authenticity demands, to convince bureaucrats, legislators, and judges of the need for flexibility in addressing domestic violence cases involving cross-border couples. Interactions among these various actors and between the actors and immigrants themselves expose how pervasive anxieties about immigration permeate bureaucratic, legal, and activist domains, making it even more difficult to breach gaps between local and immigrant women and establish a foundation for articulating shared interests.

Although cases of intimate partner violence involving immigrant wives may generate legal breakthroughs that begin to recognize the depth and complexity of domestic violence (as in the case analyzed in this Article), thus reversing a unidirectional narrative that privileges domestic law and citizens' legal activism as the source of progressive reform, these legal advances may fail to integrate immigrant women's

9. See, e.g., Balram, supra note 8 , at 389 (describing restricted access to domestic violence shelters and legal aid services due to funding restrictions); Orloff \& Kaguyutan, supra note 6, at 125-29 (noting the various bureaucratic barriers to legal services and other benefits); Shaw, supra note 8 , at 688 (describing how the restriction of public benefits for a period of five years after coming to the U.S. forces immigrant women to rely on their abusers); cf. Wood, supra note 8, at 147, 152 (explaining that although reforms restored certain public benefits, immigrant battered women cannot receive federal, state, or local benefits if the batterer is not her legal husband).

10. Dalu Diqu Renmin zai Taiwan Diqu Yiqin Juliu Changqi Juliu huo Dingju Xuke Banfa（大陸地區人民在壆涒地區依親居留長期居留或定居許可辦法) [Permit Regulations for Kinship-Based, Extended, or Permanent Residence of Peoples of the Mainland Area in the Taiwan Area] (promulgated by the Ministry of the Interior [Immigration], Aug. 12, 2009, effective Aug. 12, 2009) arts. 13, 25, 32 (Taiwan), available at http://law.moj.gov.tw/ LawClass/LawOldVer.aspx?Pcode=Q0060003\&LNNDATE=20090812\&LSER=001. 
experiences of violence and abuse into a broader societal project of combating domestic violence. Lost in the thicket of legal, bureaucratic, and activist agendas are both the futures of immigrant women who face spousal violence and the political will to advance immigration reforms by exposing the consequences of competing ethical orientations and their discriminatory logics.

In my analysis to follow, I draw on nearly two years of nonconsecutive ethnographic fieldwork conducted between 2003 and 2011 in Taiwan and China. This research incorporated cross-Strait couples and their families, Taiwan bureaucrats and officials in government units charged with regulating and supporting immigrants, and Taiwanese nongovernmental organizations (NGOs) dedicated to immigrant rights and service provision. This article derives from my direct involvement in several stages of the Zhao Yanbing case described above, including observation of court proceedings, participation in activist planning sessions and public events, and repeated interviews over the years with the defendant, the defense lawyers, judges, social workers, and activists. I situate Zhao's case in the broader context of immigration regulation and domestic violence protection in Taiwan through my research with other Chinese spouses who have faced domestic abuse and through interviews with relevant immigration authorities and social service providers.

Below, I first provide a brief overview of marital migration across the Taiwan Strait and the differential treatment of Chinese spouses as opposed to marital immigrants from other countries, primarily those from Southeast Asia. Second, I outline the competing goals and procedures of domestic violence prevention and immigration regulation in Taiwan. Third, I turn to Zhao's case and examine in detail the defense strategy during the murder trial and its feminist arguments that led to an unprecedented ruling at the District Court level. Fourth, I analyze the prosecutor's appeal and the debates that took place during the High Court sessions to show how gender biases and immigration stereotypes pervaded these subsequent legal interactions, confirming the difficulties faced by immigrant women who seek to leave abusive relationships. Fifth, I look briefly at activist strategies and press conferences to demonstrate how these biases also permeated broader social mobilization around the case and limited activists' ability to forge connections between the interests of immigrant and local women. Lastly, I follow the case through to the Supreme Court to show the difficulties of advancing a defense strategy that integrates the debilitating effects of domestic abuse with the vulnerability of immigrant status. 


\section{TAIWAN AS AN IMMIGRATION DESTINATION}

The most recent wave of marital migration across the Taiwan Strait began in 1987 with the resumption of ties between Taiwan and China following nearly forty years of separation and military conflict after the Nationalist army and government fled to Taiwan in the aftermath of China's civil war (1945-49). ${ }^{11}$ Once the ban on travel to Mainland China was lifted, various groups in Taiwan seized the opportunity to visit family members, engage in business, or tour the country, and growing numbers of Taiwan citizens also began to marry and form families across the Strait. ${ }^{12}$ The vast majority of these marriages have joined Taiwanese men and Chinese women, and they have diversified over time to encompass different sectors of the population in both locales. ${ }^{13}$ In keeping with marital norms of patrilocal residence and assumptions about a higher standard of living and better income-generating opportunities in Taiwan, many of these couples planned to reside in Taiwan. ${ }^{14}$ In 1992, the Taiwanese government passed the first legislation regulating renewed cross-Strait ties. This act, and the myriad of administrative policies that grew out of it, created a tightly controlled rubric for admitting the Chinese spouses of Taiwanese citizens into the country and defining their subsequent immigration and naturalization trajectory. ${ }^{15}$

Among the first groups to return to China after 1987 were retired veterans who had fled to Taiwan with the Nationalist army in 1949,

11. See generally ALAN M. WACHMAN, WHY TAIWAN? GEOSTRATEgIC RATIONALES FOR CHINA'S TERRITORIAL INTEGRITY (2007).

12. Yenning Chao (趙应蜜), Gongmin Shenfen, Xiandai Guojia yu Qinmi Shenghuo: Yi Lao Danshen Rongmin yu 'Dalu Xinniang' De Hunyin wei Yanjiu Anli (公民身分, 現代國家與親密生活: 以老單身榮民與 ‘大陸新娘”的婚姻爲研究案例] [Citizenship Status, the Modern Nation, and Intimate Life: A Case Study of Marriages Between Veterans and Mainland Brides], 8 TAIWAN SheHUIXUE (台潛社會學) [TAIWANESE J. Soc.] 1 (2004) [hereinafter Citizenship Status, the Modern Nation, and Intimate Life]; Yenning Chao (趙彥寧), Xiandaixing Xiangxiang yu Guojing Guanli de Chongtu: Yi Zhongguo Hunyin Yimin Nuxing wei Yanjiu Anli (現代性想像與國境管理的衝突; 以中國婚姻移民女性爲研究案例) [Imagined Modernities, Transnational Migration, and Border Control: A Case Study of Taiwan's 'Mainland Brides'], 32 TAIWAN SHEHUIXUE XUEKAN (台簒社會學刊) [TAIWANESE J. Soc.] 59 (2004) [hereinafter Imagined Modernities, Transnational Migration, and Border Control].

13. See Citizenship Status, the Modern Nation, and Intimate Life, supra note 12; Imagined Modernities, Transnational Migration, and Border Control, supra note 12.

14. Taiwanese businessmen would be the exception to this rule, since their jobs require semipermanent residence in China.

15. Dalu Diqu yu Taiwan Diqu Renmin Guanxi Tiaoli (大陸地區與台灣地區人民關係條例) [Act Governing Relations between the People of the Taiwan Area and the Mainland Area] (promulgated by the Executive Yuan, July 31, 1992, effective Sept. 18, 1992) (Taiwan). 
leaving their families behind in the mainland and creating a marginalized community of single men largely ostracized from local Taiwanese society and its marital opportunities. ${ }^{16} \mathrm{By}$ the time crossStrait ties resumed in the late 1980 s, veterans were in their fifties and sixties and faced old age with only a meager pension from the government and, in most cases, no family support. In China, they looked for wives who would return with them to Taiwan and provide care as they aged; most of these women were middle-aged and divorced or widowed, with teenage or adult children of their own. ${ }^{17}$ Many of these future wives had been pressured to retire or "step down" (xia gang) from collective and state-sector jobs with the onset of China's market reforms and they found themselves increasingly disadvantaged in a job market that favored youth and higher education. ${ }^{18}$ The women imagined that Taiwan would offer them better employment opportunities and many were attracted by their husbands' (often highly exaggerated) portrayals of comfortable living environments and financial resources. 19

By the 1990s and 2000s, two new forms of cross-Strait unions had started to emerge beyond the caretaking marriages of elderly veterans and middle-aged Chinese women. Working-class, disadvantaged, and/or disabled Taiwanese men of younger ages sought Chinese wives through matchmaking agencies, introductions from friends and family, or through fortuitous encounters during tourist travel or employment in the Mainland. In addition, as more white-collar Taiwanese men shifted to China for work and higher education, they, too, began to marry their coworkers, classmates, or women they met through the service industry

16. Not only were these men separated from civilian society in military camps and communities, but military regulations in force in the $1950 \mathrm{~s}$ barred them from marriage while they remained in the service.

17. I did interview veterans who had married younger, never-married women, some of whom bore them children. The risk faced by all wives of elderly veterans was that their husbands might die before they obtained Taiwan citizenship, an eight-year-long process that prior to the early 2000 s offered no protection against deportation for widowed Chinese spouses without minor children in Taiwan.

18. See e.g., Eva P. W. Hung \& Stephen W. K. Chiu, The Lost Generation: Life Course Dynamics and Xiagang in China, 29 MOD. CHINA 204 (2003); Tamara Jacka, Back to the Wok: Women and Employment in Chinese Industry in the 1980s, AUSTL. J. CHINESE AFF., July 1990, at 1; RE-DRAWING BOUNDARIES: WORK, HOUSEHOLDS, AND GENDER IN CHINA (BARBARA ENTWISLE \& GAIL E. HENDERSON eds., 2000); Wang Zheng, Gender, Employment and Women's Resistance, in CHINESE SocIETY: CHANGE, ConfLICT AND RESISTANCE 162 (Elizabeth J. Perry \& Mark Selden eds., 2d ed. 2003).

19. Citizenship Status, the Modern Nation, and Intimate Life, supra note 12; Yenning Chao (趙应寧), Qinmi Guanxi Zuowei Fansi Guozu Zhuyi de Changyu: Lao Rongmin de Liang'an Hunyin Chongtu (親密關係做爲反思國族主義的場域：老榮民的兩岸婚姻衝突) [Rethinking Nationalism Through Intimate Relationships: Conflicts in Cross-Strait Marriages], 16 TAIWAN ShehUIXUE [TAIWANESE Soc.] 97 (2008) [hereinafter Rethinking Nationalism through Intimate Relationships: Conflicts in Cross-Strait Marriages]. 
or introductions from friends and colleagues. Couples in this third category were closer in age and educational background, and a growing number included Taiwanese women married to Chinese men.

With increase in the different types of cross-Strait marriages, the kinds of individuals they conjoined also diversified beyond stereotypes of the poor, disadvantaged, rural, or elderly. Chinese spouses now hail from across the country, including from urban and rural areas, and they have varied educational and professional histories and previous marital trajectories. Similarly, Taiwanese spouses come from both Mainlander and native Taiwanese backgrounds; they cut across age groups and class sectors, reside across the island, and have their own, often complex, family and marital histories. ${ }^{20}$ Although many cross-Strait couples who settle in Taiwan belong to the lower-middle and working classes, that picture is gradually changing as younger, better-educated individuals marrying for the first time form unions across the Strait.

Cross-Strait marriages are part of a rapidly changing marital landscape in Taiwan that has been altered by two decades of declining domestic marriage and birth rates. Taiwan has now become a destination for immigrant spouses from Mainland China and Southeast Asia, transforming it from an immigrant-sending to an immigrantreceiving country. Like many of its regional neighbors-including Japan, South Korea, Hong Kong, and Singapore-Taiwan faces the joint pressures of a rapidly aging population and a below-replacement birth rate, and it has turned to migrant workers and immigrant wives to shore up the country's productive and reproductive capacities. ${ }^{21}$ These developments have spawned an immigration bureaucracy and regulatory regime that police cross-border mobility and immigrants' access to legally recognized rights. ${ }^{22}$

20. The term "Mainlander" refers to people who fled to Taiwan with Chiang Kaishek in the late 1940s and who hail from across China. By comparison, the term "Taiwanese" refers to people who originated from Fujian province across the Strait and have roots in Taiwan dating back to the 16th and 17th centuries. MEMORIES OF THE FUTURE: NATIONAL IDENTTTY IsSUES AND THE SEARCH FOR A NEW TAIWAN (Stéphane Corcuff ed. 2002). Despite assumptions that it is "Mainlanders" and their descendants who are marrying Chinese today, my research shows that "Taiwanese" men and women feature in equal if not greater numbers.

21. Renkou Zhengce Baipishu (Heding Ben): Shao Zinü Hua, Gaoling Hua Ji Yimin 八口政策白皮書 [核定本]: 少子女化, 高齡化及移民) [POPULATION POLICY WHITE PAPER (RATIFIED VERSION): DECLINING BIRTHS, AGING POPULATION, AND IMMIGRATION] (2007) (Taiwan), available at http://www.immigration.gov.tw/public/Data/07148491371.pdf.

22. Taiwan's National Immigration Agency (NIA) was established in January 2007 under the auspices of the Ministry of the Interior. The Agency integrated staff and responsibilities from six different government entities, but has been dominated by staff from former police units who comprise approximately seventy percent of the total personnel. Its inauguration established an unprecedented bureaucratic reorganization 
Immigrant spouses are the largest category of foreigners eligible for naturalized citizenship in Taiwan, and yet they are not treated uniformly. Precisely because of the history of contested political ties across the Strait and China's steadfast refusal to recognize Taiwan as a sovereign nation-state, the Taiwanese government has created distinct immigration laws and policies for Mainland Chinese that reflect their exceptional status in Taiwan as neither foreigners nor natives. ${ }^{23}$ This separate immigration regime has worn heavily on Chinese spouses specifically, the largest group of marital immigrants to Taiwan and generally the only Mainland Chinese who enjoy the right to citizenship. Unlike their foreign counterparts who become eligible for citizenship after four years, Chinese spouses were required to wait a minimum of eight years prior to 2009 , at which point policy revisions reduced the wait to six years. ${ }^{24}$ And whereas foreign spouses receive residency and legal work rights immediately upon first entry, Chinese spouses faced a delay of two years for residency and two to six years before obtaining work rights (disparities that were only equalized in August 2009). ${ }^{25}$ Hence, although both Chinese and "foreign" spouses enter Taiwan through marriage to a citizen, their experiences as immigrant spouses often diverge significantly due to the disparate regulatory regimes they face and the different kinds of anxieties their presence provokes among the Taiwanese people.

Even with the 2009 reforms, the extended time to citizenship and the requirement that Chinese spouses progress through multiple visa and residency stages have made them especially vulnerable to the

that, for the first time, charged a single government agency with monitoring both foreigners and Mainland Chinese in Taiwan. See Hsiao-chuan Hsia, The Development of Immigrant Movement in Taiwan: The Case of Alliance of Human Rights Legislation for Immigrants and Migrants, 37 DEV. \& Soc'Y 187, 194-97 (2008).

23. This status question has more than semantic consequences. If Taiwan were to recognize Mainland Chinese as foreigners, the Chinese government would view that act as a statement of Taiwanese independence and respond accordingly, possibly with military force. By contrast, official identification of Chinese as ben guo ren (natives) would be perceived domestically as a move toward reunification with the Mainland, provoking a backlash from pro-independence and status quo factions in Taiwan. In essence, the government had no choice but to create a separate status for Mainland Chinese, but it did not have to make that status fundamentally unequal to other foreigners.

24. The 2009 reforms were a culmination of efforts to equalize treatment of the two groups that brought together immigrant rights NGOs, a recently elected administration that favored closer ties with China, and newly appointed officials under pressure to conform to international human rights standards.

25. For pre-2009 delays in residency and work rights, see Dalu Diqu yu Taiwan Diqu Renmin Guanxi Tiaoli (大陸地區與台雗地區人民關係條例) [Act Governing Relations between the People of the Taiwan Area and the Mainland Area] (promulgated by the Executive Yuan, July 31, 1992, effective Sept. 18, 1992) art. 17 (Taiwan). 
challenges of this particular kind of cross-border marriage. ${ }^{26}$ These marriages combine often-shaky interpersonal foundations and a potentially unstable mixture of intimacy and bureaucratic regulation with an undercurrent of political tension that tars all Chinese spouses with the brush of suspicious marital motives. Different expectations for appropriate gender roles and behavior across the Strait also fuel marital conflict and societal discrimination, particularly when Chinese women are perceived as forceful, direct, and self-interested, all patently nonfeminine traits from the perspective of many Taiwanese. ${ }^{27}$ Middleaged and older Chinese wives, most of whom are in "caretaking marriages" with elderly veterans, attract the greatest attention and concern from immigration bureaucrats, the media, and citizens more generally. ${ }^{28}$ Their unions disrupt idealized visions of marriages based on love-as do cross-border marriages more generally ${ }^{29}$-and their very presence in Taiwan underscores the uncomfortable intertwining of marital decisions and material motives, thereby provoking repeated evaluations of their marital authenticity.

\section{MARITAL FAILURE AND THE DOUBLE AUthentiCITY BIND}

Because all marital immigrants to Taiwan enter the country as "kin dependents," their legal standing prior to naturalization is tied to the continuation of their marriage and the assistance of their guarantor, who is typically their citizen-spouse or immediate conjugal kin. ${ }^{30}$ For Chinese wives and husbands, progressing through the various visa and residency stages, obtaining a work permit (prior to 2009), and processing the paperwork necessary to extend documents before they expire requires active cooperation from their Taiwanese partner in the form of appearing at immigration offices, completing paperwork, and

26. Id.

27. See Sara L. Friedman, Mobilizing Gender in Cross-Strait Marriages: Patrilineal Tensions, Care Work Expectations, and a Dependency Model of Marital Immigration, in Mobile Horizons: DYNamics Across THE TaIWAN STRAIT (Wen-hsin Yeh ed., forthcoming 2012-13).

28. See Rethinking Nationalism through Intimate Relationships: Conflicts in CrossStrait Marriages, supra note 19.

29. See Pei-Chia Lan, Migrant Women's Bodies as Boundary Markers: Reproductive Crisis and Sexual Control in the Ethnic Frontiers of Taiwan, 33 SIGNS: J. WOMEN CUlTURE \& Soc'Y 833, 846-48 (2008).

30. Dalu Diqu Renmin zai Taiwan Diqu Yiqin Juliu Changqi Juliu huo Dingju Xuke Banfa (大陸地區人民在荎灣地區依親居留長期居留或定居許可辦法) [Permit Regulations for Kinship-Based, Extended, or Permanent Residence of Peoples of the Mainland Area in the Taiwan Area] (promulgated by the Ministry of the Interior [Immigration], Aug. 12, 2009, effective Aug. 12, 2009) art. 5 (Taiwan). 
providing copies of official identification documents. ${ }^{31}$ Should the Taiwanese spouse or his family members refuse to participate in this process, the Chinese spouse may find herself unable to progress to the next immigration stage or, worse, saddled with expired documents that put her at risk for deportation.

Chinese and foreign spouses alike are vulnerable to the whims of their citizen spouse as they secure this kin-dependent residency and citizenship in Taiwan. The differences between them, however, are ones of both degree and quality. Foreign spouses face obstacles to secure legal status and societal integration that derive from linguistic, cultural, and racial differences with Taiwanese. However, they also are perceived as more vulnerable because of their lack of linguistic and cultural competence, and hence when they do experience abuse, they are seen more sympathetically as "victims."

Chinese spouses, on the other hand, have certain advantages with regard to language and cultural familiarity, but this may work to their disadvantage. Because they face a longer time to citizenship and are required to progress through multiple immigration stages, they encounter greater procedural risks since each stage in the process brings its own requirements of marital authenticity and guarantor support. Moreover, Chinese spouses experience greater bureaucratic and societal suspicion about the authenticity of their marital motives. This suspicion not only affects their ability to resolve marital conflicts successfully; it also makes bureaucrats, lawyers, and social workers less inclined to assist Chinese spouses when the marriage founders. In cases of domestic violence and divorce, an immigrant Chinese spouse who makes use of existing legal and social resources may be viewed not as vulnerable and in need of aid but as a savvy manipulator who uses the system to her advantage. ${ }^{32}$

In brief, if they remain married, Chinese spouses find that prior to naturalization, their citizen-spouse wields a great deal of power as their guarantor. If the marriage ends in divorce, their only recourse to remain legally in Taiwan is to transfer their kin-dependency to a minor citizen-

31. Id. arts. 6, 13, 26, 31. On pre-2009 work permit application requirements, see Dalu Diqu Pei'ou zai Taiwan Diqu Yiqin Juliu Qijian Gongzuo Xuke ji Guanli Banfa (大陸地區配偶在台羟地區依親居留期間工作許可及管理辦法) [Management Procedures and Work Permission for Mainland Spouses in Taiwan during Kin-Dependent Residency Period] Aug. 12, 1998, available at http://aw.moj.gov.tw/LawClass/LawAll.aspx?PCode=N0090036.

32. See Chen Yi (陳儀), Zaoshou Hunyin Baoli Nüxing Dalu Pei'ou de Qiuzhu Kunjing yu Shengcun zhi Dao (遭受婚姻暴力女性大陸配偶的求助困境與生存之道) [Help-seeking Predicaments and Paths to Survival for Female Mainland Spouses Who Suffer Marital Violence], at 87-91 (Feb. 2010) (unpublished M.A. thesis, National Chung Cheng University) (on file with author). 
child through obtaining legal child custody. ${ }^{33}$ Death of the Taiwan partner prior to the last residency stage and in the absence of dependent children resulted in deportation for the Chinese spouse before 2009 (at which point, protection against deportation was extended to the first residency stage) ${ }^{34}$ Only widowed Chinese spouses with a minor citizenchild qualified immediately for citizenship.

The emphasis on having a citizen-child who can legitimate a Chinese spouse's kin-dependent status shows how difficult, indeed, is the effort to retain a recognized status in Taiwan outside of marriage. Nor is this effort merely a legal task, for the very desire for independent standing exposes Chinese spouses to heightened authenticity concerns from bureaucrats, judges, and social service providers alike, regardless of the difficulty of their circumstances. Subject to questions about the validity of both their marriage and the reasons for ending it, Chinese spouses face a double authenticity bind that embroils them in conflicts between legal domains. These conflicts are most pronounced in cases of spousal abuse, which bring domestic violence laws and immigration policies into direct confrontation.

The first decade of the new millennium sparked greater attention in Taiwan to the problem of domestic violence in cross-border marriages. Newspapers repeatedly printed stories about immigrant wives from China and Southeast Asia who remained in abusive marriages because leaving required that they abandon their children and life in Taiwan. These accounts were sometimes paired with tales of elderly veterans abused by their younger Chinese wives, as well as stories about immigrant spouses who "faked" or "provoked" domestic violence in order to obtain a shortcut to citizenship. ${ }^{35}$ In the second half of the decade,

33. Permit Regulations for Kinship-Based, Extended, or Permanent Residence of Peoples of the Mainland Area in the Taiwan Area, art. 14-4. The child custody requirement has fueled suspicion among judges and immigration bureaucrats that applications for child custody are "merely" a means to stay in Taiwan to earn money.

34. A 2008 policy revision allowed childless Chinese spouses who had reached the final residency stage when their citizen-spouse died to apply for citizenship after an additional three years at this stage, assuming they did not remarry and resided in Taiwan for more than 183 days per year. $1 d$. art. 34. In August 2009, this benefit was granted to childless spouses whose Taiwanese partner died at the first residency stage, and the extra waiting period at the final stage was reduced to two years. Id. arts. 13,32 .

35. E.g., Lin Jiadong, Xiang Chengzhen, \& Liu Zhiyuan, (林嘉東, 項程鎭, \& 劉志原) Sheji Laogong Jiabao: Waipei Liu Tai Jiejing? (設計老公家暴 外配留台捷徑?) [Instigating Husband's Domestic Violence: A Shortcut for Foreign Spouses to Stay in Taiwan?], ZrYOU SHIBAO (自由時報) [LIBERTY TIMES], July 4, 2011, available at http://www.libertytimes.com.tw/2011/new/jul/4/today-so11.htm. For an insightful analysis of this phenomenon that emphasizes the role of discriminatory policies in encouraging immigrant wives to incite domestic violence, see Imagined Modernities, Transnational Migration, and Border Control, supra note 12, at 81-84. 
various units in the Ministry of the Interior began to revise policies and procedures for addressing cases of domestic violence involving immigrant spouses. The 2009 policy reforms enabled Chinese spouses who divorced due to domestic violence and who had minor children in Taiwan to remain legally in the country and progress toward citizenship even without child custody. ${ }^{36}$ Yet efforts by NGOs and social workers to push for more lenient treatment for nonprocreative spouses who failed to meet these standards frequently encountered resistance from immigration bureaucrats and policymakers suspicious about abuse claims. ${ }^{37}$

In most cases, bureaucrats require a court-issued protection order (tongchang baohuling) as proof of domestic violence when Chinese spouses want to change their guarantor in order to renew soon-to-expire documents or apply for the next immigration stage. ${ }^{38}$ A protection order also mitigates suspicions about an abused spouse who leaves her husband's residence to move to a domestic violence shelter or other location, and provides crucial legal proof if her husband were subsequently to report her to the police as missing, an accusation that might derail a future application for residency or citizenship. Not all women who suffer from domestic violence qualify for a protection order, however, and those who had either already fled their abuser or been forced to move out might very well fail to qualify if a judge deems them not to be in immediate danger. Zhao Yanbing had successfully obtained two protection orders in part by continuing to live with her husband (and, hence, continuing to experience abuse). ${ }^{39}$ Yet because she and her

36. Permit Regulations for Kinship-Based, Extended, or Permanent Residence of Peoples of the Mainland Area in the Taiwan Area, art. 13-4.

37. On the importance of the kin-dependent tie, see Chen, supra note 32, at 13.

38. Jingcha Jiguan Chuli Dalu Diqu Ji Waiji Pei'ou Zao Shou Jiating Baoli Anjian Yingxing Zhuyi Shixiang (繁察機關處理大陸地區及外籍配偶遭受家莛暴力案件應行注意事項) [Matters Police Units Should Pay Attention to When Handling Cases of Domestic Violence Involving Mainland Chinese and Foreign Spouses], (promulgated by the Ministry of the Interior (Police), July 15, 2005, effective July 15, 2005) (Taiwan), available at http:/www.cib.gov.tw/CibSystem/RE_UPLOAD_FILE/2007921192921.pdf. Although neither the original document nor the revised version of July 15, 2005 (Fagui 139) explicitly required a protection order as proof of domestic violence, immigration bureaucrats nonetheless have adopted it as regular procedure. Permit Regulations for Kinship-Based, Extended, or Permanent Residence of Peoples of the Mainland Area in the Taiwan Area, art. 5. Approval for a change in guarantor has remained subject to bureaucratic discretion, and Chen documents numerous examples of abused spouses who failed in their efforts to make use of this exception. Chen, supra note 32 , at 81 . In my research, I encountered only one case where a nonprocreative Chinese woman successfully applied for the next residency stage without her husband serving as a guarantor, and in this instance her social worker was willing to act in that capacity.

39. Just prior to the murder, Zhao's social worker had urged her to move to a shelter during the New Year holiday but because of her fragile physical and mental health, Zhao 
husband slept in separate rooms, the question of immediate threat and separate accommodations also reemerged during her trial when the public prosecutor used their sleeping arrangements to challenge the extent of Zhao's abuse. ${ }^{40}$

These examples underscore the complexity of joint residence expectations for cross-Strait couples: not only does spousal coresidence undergird official definitions of authentic marriage, but it also is critical to abused spouses' efforts to obtain the kind of legal recognition of domestic violence required by immigration bureaucrats. In turn, cases that deviate in some way from this official model of authentic marriage and authentic domestic violence, whether willingly or by force, expose the divergent logics undergirding court-issued protection orders and domestic violence prevention, on the one hand, and immigration regulation, on the other. By putting responsibility on the courts for determining whether an immigrant spouse is a victim of domestic violence, immigration policymakers and bureaucrats have introduced an inherent contradiction into the procedural channels that lead to naturalized citizenship, forever barring some abused immigrants from the protections guaranteed under civil law. Although the 2009 revisions worked around the edges of immigration regulation to ease the plight of procreative Chinese spouses who experienced domestic violence, they failed to redress the underlying suspicions about immigrants' marital motives that drove a wedge between procedures for establishing residency and citizenship eligibility and protections offered under civil law for those who suffer domestic abuse. This persistent gap has generated serious consequences for women such as Zhao Yanbing whose childless marriages produce no alternative kin-based anchor to justify their legal residence in Taiwan. Hence, were Zhao to experience spousal abuse today, she would likely face the same limited choice: either divorce and be forced to return to China or remain in an abusive marriage in order to retain her legal standing in the country.

\section{WHEN AN IMMIGRANT WIFE KILLS HER CITIZEN-HUSBAND41}

I learned of Zhao Yanbing's case after the Taipei District Court issued an unprecedented ruling in September 2007, sparking several

was not willing to subject herself to a collective living environment, nor did she have friends or relatives who could take her in.

40. See infra Part IV.

41. The analysis in this section is based on the author's interviews with the defendant, the lawyers who worked on Zhao's case, and the head district court judge, in addition to the legal documents from the trial. Personal observations and interviews took place in Taipei, Taiwan from September 2007 - July 2011. 
days of intense media coverage and press conferences sponsored by women's and immigrant rights' groups. ${ }^{22}$ The panel of judges found that fifty-three-year-old Zhao had acted in "self-defense" (zhengdang fangwei) when she killed her seventy-something husband, Jia Xinmin, although they also found her actions to be excessive. ${ }^{43}$ Hence, they reduced her sentence to eighteen months. ${ }^{44}$ Never before in the history of intimate-partner violence in Taiwan had a court issued such a lenient ruling to a female defendant, much less one of immigrant background. ${ }^{45}$

Although the ruling built carefully on the details of the case, it was also the product of the specific personalities involved in the trial: a liberal-minded head judge from a nontraditional legal background and a feminist lead defense lawyer who had many years of experience working on behalf of abused immigrant wives in Taiwan. ${ }^{46}$ After encouragement from the judge, the defense drew openly on American feminist jurisprudence introduced by Taiwanese legal scholars and on the work of liberal immigration scholars in Taiwan as they crafted their argument. The defense began by framing cross-Strait marriages in terms of globalization and regional economic inequality in order to grant legitimacy to marital immigrants' economic motives. With great care, the defense showed how these inequalities in cross-border marriages were exacerbated by Taiwan's discriminatory policies toward Chinese spouses specifically, which thereby intensified veteran-husbands' longstanding ideological and personal prejudices against Mainland Chinese and their inclination to turn to violence to resolve interpersonal conflicts. ${ }^{47}$ This combination created an incendiary mixture that could

42. Taipei Dist. Ct. Pub. Prosecutor v. Zhao Yanbing (台北地方法院檢察署檢察官 v. 趋岩冰), (Taipei Dist. Ct. Sept. 27, 2007), available at http:/tadels.digital.ntu.edu.tw/ browse/archive_brouse/single.php?\&p=1\&num=A_0002_0001_002.

43. The Chinese term, zhengdang fangwei, translates literally as "legitimate defense." I use the recognized U.S. legal term throughout.

44. The standard minimum sentence for murder is ten years.

45. The precedent-setting case for spousal murder in response to domestic violence is Taiwan Banqiao Dist. Ct. Pub. Prosecutor v. Deng Ruwen (台第板橋地方法院检察署檢察官 v. 鄧如雯), (Banqiao Dist. Ct. Feb. 23, 1994), available at http://tadels.digital.ntu.edu.tw/ browse/archive_brouse/single.php?\&p=1\&num=A_0002_0003_001.

46. Unlike many legal professionals in Taiwan, this judge came from a working-class family and received his initial training in the field of education, only later sitting for and passing the exam to become a judge. Interview with Lin Menghuan, Taipei District Court Judge, Taipei, Taiwan (July 2, 2008). The lawyer, who was employed by a prominent law firm, had taken the pro bono case on behalf of a nonprofit, antidomestic violence organization called the Women's Rescue Foundation.

47. Veterans' ideological prejudices were a product of the Cold War ideology instilled in them through years of military service. Jia Xinmin's hatred of the Chinese communists also derived from personal experience, for his father had been shot to death by Red Army soldiers during the civil war (1945-49). 
easily erupt in domestic violence, a tragedy likely to persist over time because a Chinese wife such as Zhao could not leave an abusive husband without jeopardizing her immigration status and risking deportation. Nor could many of these women, Zhao included, imagine an acceptable route home that did not involve humiliation for themselves and great disappointment for their families.

The defense painted a picture of Zhao as a typical woman of her generation: modest, self-motivated, selfless, and obedient to the party. Her professional success as a high-ranking scientist and cadre, they argued, made the humiliation and psychological and physical abuse inflicted on her by Jia all the more unbearable. Before she met Jia, Zhao was a widow with a daughter who was studying in the United States. Introduced to Jia Xinmin by an acquaintance in the Taiwan Affairs Office of her regional home city, she fell for Jia's self-portrayal as a wealthy, never-married businessman, trusting him in part because he was a Christian. Zhao retired early from her post in a state research institute and married Jia in 2003, only to discover after she moved to Taiwan that he had misrepresented his financial, professional, and personal particulars.

Jia's abusive behavior began early on, but when Zhao sought advice from the acquaintance who had introduced them, she was discouraged from leaving the marriage because of the way it symbolized broader improvements in cross-Strait ties. After the couple moved to Taiwan, Jia became increasingly controlling and abusive, beating and cursing her at the slightest provocation and restricting her movements, social interactions, and access to financial resources. He provided no care after she was diagnosed with cervical cancer in late 2004, refusing to visit or support her during several hospital stays, and she, isolated from any community of friends or family in Taiwan, quickly slid into depression and mental illness.

The defense built a three-pronged argument to support Zhao's case. ${ }^{48}$ First, they argued for a heat-of-passion ruling (yifen sharen) which in the Taiwan criminal code carried the connotation of popularly recognized righteous anger (yifen) provoked by socially condemned behavior. ${ }^{49}$ The defense traced the history of that article in the criminal code and Supreme Court interpretations to show how it was rooted in gendered societal values that reflected masculine privilege; for example, exonerating a husband who killed his wife after catching her having sex

48. Xingshi Zonghe Bianhu Yizhi Zhuang (刑事綜合護意旨狀) [Final Defense Argument] (Aug. 15, 2007) (on file with author).

49. Zhonghua Minguo Xingfa (中華民國刑法) [Criminal Code of the Republic of China] (Nov. 30, 2011) art. 273 (Taiwan), available at http:/law.moj.gov.tw/LawClass/ LawAll.aspx?PCode $=$ C0000001. 
with her lover. Arguing that Taiwan's passage of a domestic violence prevention act in 1998 and other legal reforms with respect to gender and sexual violence reflected significant changes in societal values over time, the defense claimed that Jia Xinmin's treatment of Zhao prior to and on the morning of the murder would have incited a response of popular anger and, therefore, Zhao's act should be viewed as a socially recognized, heat-of-passion reaction to provocation.

The second prong in the defense's case was to argue that Zhao's response to Jia's threatening behavior constituted self-defense (zhengdang fangwei). Again, the defense unpacked the gender bias in this article of the criminal code by showing how previous interpretations of the article had privileged male reactions to violent attack, assuming physically matched combatants and an immediate counter-attack to deflect present danger. ${ }^{50}$ Drawing on recent revisions to sexual violence laws that mitigated excessive force requirements and emphasized the presence or absence of consent, the lawyers argued that women typically responded differently to violence and that Taiwan's judiciary lacked awareness of the male bias in traditional legal thinking. The special circumstances of battered women required attention to their ongoing sense of threat and imminent danger, and the defense explicitly identified Zhao as suffering from battered women's syndrome, a version of post-traumatic stress disorder. When faced with Jia's brandishing of a knife and threat to kill her-a threat he had made in the past-Zhao truly believed her life was in danger and thus she acted to defend herself.

Finally, the defense made an argument for Zhao's impaired mental state (jingshen haoruo) at the time that, when coupled with her poor physical condition, compromised her ability to think or make judgments rationally. Under severe pressure and unable to control her impulsive behavior (in part because she had not refilled her prescription for antidepression medication), she had responded in a manner that reflected a psychological and emotional breakdown. The defense pointed to the fact that Zhao stabbed Jia multiple times after he was already unconscious as proof of her loss of control. Summing up their argument, the defense called on the court to consider the defendant's special circumstances as an immigrant woman faced with domestic violence who was under severe physical and psychological distress at the time of the murder. They requested a suspended sentence and acknowledged that she would leave the country after the conclusion of the court case.

The district court ruling, issued on September 27, 2007, reiterated many of the arguments made by the defense concerning the unique

50. Id. art. 23. 
circumstances of immigrant spouses-especially those faced with domestic violence-and the unequal power relations that characterized cross-Strait marriages. ${ }^{51}$ The court also recognized that these unequal power relations were exacerbated by the personal and political histories of elderly veteran husbands in particular. The judges acknowledged the specific nature of battered women's experiences and they corroborated the defense's argument that such experience should serve as the basis for evaluating the defendant's behavior. ${ }^{52}$ In the end, however, they rejected two of the three defense claims: heat-of-passion and an impaired mental state. ${ }^{53}$ Finding that the defendant did act in legitimate defense, the judges nonetheless added that Zhao's behavior was excessive, pointing specifically to her stabbing Jia to death after she had already knocked him unconscious. ${ }^{54}$

In their sentencing statement, the judges reiterated their interpretation of Zhao's excessive behavior as a rationale for issuing a reduced sentence instead of declaring her not guilty. ${ }^{55}$ Their explanation emphasized her educated background in China and her marked social, physical, and psychological decline after moving to Taiwan and experiencing Jia's abusive treatment. ${ }^{56}$ Taking care to underscore Zhao's willingness to care for Jia when he was hospitalized early in their marriage, the judges both acknowledged and put to rest authenticity concerns about Zhao's marital motives by stressing her conformity to the standards of a caretaking marriage:

Although the defendant hoped to come to Taiwan to earn
money and advance herself, out of a desire for life in
Taiwan, she also actively maintained her marriage,
caring for Jia Xinmin and integrating into Taiwan

51. Taipei Dist. Ct. Pub. Prosecutor v. Zhao Yanbing (台北地方法院檢察署檢察官 v. 趋岩冰), at 14-16 (Taipei Dist. Ct. Sept. 27, 2007), available at http://tadels.digital.ntu.edu.tw/browse/ archive_brouse/single.php?\&p=1\&num=A_0002_0001_002.

52. Id. at $12-14$.

53. Id. at $7,10-11,25-27$.

54. Id. at 21-22, 31-32.

55. Id. at 35. Zhao's reduced sentence was also a consequence of the fact that she had turned herself in to the authorities, an action that legally constituted cause for reduction of sentence. See id. at 33. In this finding of excessive self-defense, one also sees how the reasonableness standard of self-defense worked against Zhao because the judges applied the standard to both actions (hitting Jia with the hammer and stabbing him with the knife), and found her lacking in the second act. In other words, they did not feel compelled to re-evaluate the reasonableness standard itself given the context of a battered woman defendant. See ELIZABETH M. SchNEIDER, BATTERED WOMEN \& FEMINIST LAWMAKING 117 (2000).

56. Taipei Dist. Ct. Pub. Prosecutor v. Zhao Yanbing (台北地方法院檢察署檢察官 v. 趋岩冰), at 33-35. 
society. She did not come to Taiwan purely for the purpose of earning money and she displayed good conduct (emphasis added). ${ }^{57}$

This closing emphasis on Zhao's adherence to the caretaking principles that shored up official standards for authentic cross-Strait marriages resituated the judges' ruling on the uneven terrain of domestic violence protection and immigration control. From the perspective of gender equality and women's rights, the ruling established a new precedent for spousal murder in cases of domestic violence by acknowledging how the emotional and psychological impact of domestic abuse intensified a woman's perception of imminent threat from her abuser, thereby justifying the court's finding of self-defense (although tempered in this case by excessive action). At the same time, however, the imperative to confirm the authenticity of Zhao's marital motives diminished the impact of this unprecedented ruling for immigrant spouses by suggesting that marital authenticity constituted a precondition for recognizing battered women's syndrome in crossborder unions. Whether intentionally or not, the judges reaffirmed immigrant women's subjection to two distinct standards for evaluating violent responses to spousal abuse, adding the burden of marital authenticity demands to the patriarchal gender inequalities that until now had shaped judicial rulings in cases where battered women killed their abusers.

\section{A ClASH OF LEGAL REGIMES 58}

The argument crafted by the defense powerfully mobilized a feminist interpretation of immigrant insecurity and domestic violence to present a case sensitive to the specific marital, economic, and legal pressures faced by Zhao Yanbing. The district court judges used these arguments to buttress their finding that the defendant suffered both from battered women's syndrome and unequal status as an immigrant. At the same time, however, their ruling clearly identified Zhao as a member of a class of spouses whose immigrant standing required that they prove their conformity to a particular model of marital authenticity premised on female dependency and care provision. These gendered features of a presumably authentic cross-Strait marriage began to

57. Id. at 34 .

58. My analysis in this section is based on my reading of the relevant legal and court documents, observation of High Court sessions (from December 2007 through June 2008), and interviews with the defendant and defense lawyers. 
feature ever more prominently as the case made its way through higher levels of the court system.

Immediately following the lower court ruling, the public prosecutor appealed the decision to the High Court (gaodeng fayuan). ${ }^{59}$ The appeal is striking for the way it affirms gendered stereotypes of domestic violence victims and presumes a traditionally patriarchal standard for marital relationships. Although recognizing the discordant nature of Zhao and Jia's marriage, the appeal nonetheless questioned who should be identified as the victim in their relationship. The appeal undermined Zhao's claim to victimization by challenging her status as an appropriately weak and submissive female supplicant, a critique that also underscored, albeit implicitly, Mainland Chinese women's more assertive behavior and strong sense of self-interest, traits that conflict with traditional Taiwanese gender roles. ${ }^{60}$

The prosecutor began by questioning whether the defendant truly qualified as an abused woman who suffered long-term domestic violence. To undermine that status, the prosecutor reframed the couple's conflicts over money and spousal support as a sign of Jia's frugality in the face of Zhao's excessive financial needs (especially to support her daughter in the United States). In response to Zhao's public complaints about Jia's refusal to support her and her repeated loans from neighbors, the prosecutor concluded that "as a husband, the victim certainly would hope that his own spouse would not flaunt herself in public [pao tou lou mian] by earning money or borrowing from neighbors."61 The prosecutor's portrayal of Zhao's desire to work outside the home as "flaunting herself in public" invoked a vision of female domesticity dramatically at odds with the experiences of most Taiwanese and Chinese women today. By emphasizing the naturalness of such a response on Jia's part ("the victim certainly [dangran] would hope"), the appeal also gestured not-so-subtly toward Zhao's inappropriate material desires as an immigrant wife, hence raising questions about the authenticity of her marital motives.

The prosecutor further challenged Zhao's status as a victim of domestic violence by evaluating her behavior against an imagined stereotype of a battered woman. By applying for protection orders and seeking assistance from social workers and the police, she did not

59. Taiwan Taipei Difang Fayuan Jiancha Shu Jianchaguan Shangsu Shu (台北地方法院檢察署檢察官上訴書) [Taipei Dist. Ct. Pub. Prosecutor App.], (Nov. 14, 2007) (Taiwan), available at http://tadels.digital.ntu.edu.tw/browse/archive_brouse/ single.php?\&p=1\&num=A_0002_0001_003.

60. Friedman, supra note 27.

61. Taiwan Taipei Difang Fayuan Jiancha Shu Jianchaguan Shangsu Shu (台北地方法院檢察署檢察官上訴書) [Taipei Dist. Ct. Pub. Prosecutor App.], at 1. 
"meekly accept her humiliations" nor did she conform to "the role of the simple, abused [woman]."62 Repeated references to Zhao's high level of education undermined her claims to victimization, while depictions of her emotional instability and conflicts with neighbors created a portrait of a quarrelsome woman who perhaps incited the violence she claims was inflicted on her. Descriptions of her injuries as merely "light" bruises on her limbs also diminished the extent of her abuse and, when combined with the picture of her as quick to anger, added to the prosecutor's questioning of her victim status. Ultimately, the public prosecutor called on the High Court to reconsider the finding of selfdefense by arguing that Jia's behavior in the moment did not constitute an immediate threat and by reframing Zhao's reaction that fateful morning as a decision "to end this unhappy marriage by terminating the other party's life, a path to resolution obviously not in conformity with the law."63

As the case moved on to hearings in the High Court, the judges addressed the specific points raised in the appeals of both the prosecutor and the defense. ${ }^{64}$ During the court hearings, extending from December 2007 through June 2008, the judges intently questioned Zhao and the defense on the three main points of the prosecutor's appeal: whether she was, in fact, a long-term victim of domestic violence; whether her actions constituted legitimate self-defense; and whether her sentencing was too light. The exchanges revealed not only the court's conservative response to domestic violence, but also the judges' difficulty grasping the specific gender inequalities and legal status pressures that characterize cross-border marriages.

One of the more detailed exchanges took place during the second court session on March 11, 2008.65 With a new head judge and public prosecutor in place, the session began with responses from Zhao and the defense lawyers to the issues raised in the prosecutor's appeal. The lead judge then read out a summary of Zhao's personal history and how she met Jia Xinmin, after which he asked Zhao whether she knew Jia's economic circumstances at the time they married. Zhao responded forcefully that she had no understanding of his finances from the day they married until the day he died. Incredulous, the judge asked again,

62. Id. at 2 .

63. Id. at 4.

64. Taipei Dist. Ct. Pub. Prosecutor v. Zhao Yanbing, (台北地方法院檢察署檢察官 v. 趋岩冰) (Taiwan High Ct., Crim. Div., June 24, 2008) (Taiwan), available at http://tadels.digital.ntu.edu.tw/browse/archive_brouse/single.php?\&p=1\&num=A_0002_00 01_007. The defense appeal reiterated both arguments struck down by the lower court: heat of passion and impaired mental state.

65. This section is based on written notes taken by myself and my research assistant during the court session. 
"How could you not know?," to which Zhao retorted that Jia had even kept from her the amount of his monthly pension and his military rank upon retirement, responding to her queries about the latter by slapping her across the face.

Clearly puzzled by this arrangement, the judge asked when Jia began abusing her. Zhao replied that he physically and verbally assaulted her from the first day of their marriage, to which the judge responded, "But he gave you a living stipend, yes?" When Zhao denied that Jia had supported her, even at the most basic level of a caretaking union, the judge, somewhat exasperated at this point, queried why she did not leave him given how poorly he treated her. Zhao first defended her decision to remain in the marriage by describing the loss of face she would experience were she to divorce him, especially because her superiors and colleagues had attended their wedding banquet in China. As if sensing the judge's disapproval, however, she hesitated and invoked the caretaking model, adding that she also recognized that Jia was in poor health and, like her, had no family in Taiwan; therefore, she thought that if she treated him better, their relationship might improve.

Ignoring Zhao's portrayal of her commitment to a caretaking marriage, the judge continued to question her about economic motives, asking, "You hoped to find a job [in Taiwan] and earn money, right?" When Zhao replied in the affirmative, the judge proceeded with questions about her work experience, and the tenor of his inquiry conveyed a palpable sense of doubt about her commitment to the marriage itself, as if to suggest that her primary motive was to benefit from the more lucrative employment opportunities in Taiwan. Zhao herself contributed to this interpretation when, in response to the judge's repeated questions about her sequence of actions on the morning of the murder (all intended to establish whether the murder was premeditated), she protested that had she wanted to kill Jia, she could easily have done so on earlier occasions because of his poor health. Instead, she had resuscitated him numerous times and called for an ambulance. She had no desire to see him dead, Zhao continued matterof-factly, because she wanted to obtain a work permit and citizenship in Taiwan. The judge visibly recoiled upon hearing this last statement, his body tensing briefly, as if her words had finally confirmed his distrust of her instrumental marital motives and his inability to comprehend the rationale behind the couple's marriage. A split-second of silence conveyed his displeasure to the courtroom, and the lead defense lawyer quickly intervened to request permission to offer supplementary commentary.

The judge's verbal and physical responses to Zhao's testimony reveal a gap in comprehension that cuts across the domains of domestic 
violence and immigration. As the lead defense lawyer explained to me, because judges have been trained in a mode of legal thinking that emphasizes a linear sequence of cause and effect, motive and action, they have difficulty grasping the apparent irrationality and nonlinearity of domestic violence-related crimes. Hence, during the court hearings, the judge repeatedly questioned Zhao about the sequence of actions that led her to take up the hammer and seize the knife, and he was profoundly disturbed by her claim not to know how the knife ended up in her hand or why she killed her husband.

The judge's inability to understand why Zhao stayed in the marriage when faced with such abuse was compounded by his incomprehension of the tensions and inequalities specific to cross-Strait marriages. This lack of understanding was conveyed in the second court session by his astonished response to Zhao's statement that Jia never shared with her the details of his financial situation. ${ }^{66}$ Instead of considering the diverse ways that Jia's control over Zhao was buttressed by the state (which Jia represented in his role as her legal guarantor), the judge moved quickly to conclude that because Zhao's marital motives were material-to work and earn money. in Taiwan-she irrationally remained in an abusive marriage, the authenticity of which he had already deemed suspect.

This case's integration of domestic violence and immigrant standing made it difficult to situate within existing legal frameworks. It brought into relation disparate legal regimes-domestic violence/criminal law and immigration policy - that did not fit neatly with one another and required very different forms of expertise (and all of the judges claimed unfamiliarity with immigration regulations). Moreover, the ethical orientations invoked by domestic violence protections and immigration policies-feminist, paternalistic, and humanitarian on the one hand, and nationalist and protectionist on the other-clashed with noticeable force in the responses of most of the legal professionals involved in the case, the defense lawyers aside. Even the district court head judge confessed to me that he struggled to decide which category should serve as the basis for his ruling and whether Zhao's lawyers were correct in arguing that provocation in the heat of passion could be combined with self-defense. ${ }^{67}$ The heat of passion argument challenged pervasive stereotypes of Chinese spouses in Taiwan and it demanded government accountability for creating immigration policies that fostered a social climate conducive not only to suspicion and discrimination, but also

66. Taiwanese spouses' refusal to share financial information with their immigrant partners is a common feature of cross-border marriages in general and cross-Strait marriages specifically.

67. Interview with Taipei District Court Judge Lin Menghuan, supra note 46. 
abuse, especially on the part of the citizen-spouse/guarantor. ${ }^{68}$ The junior member of the defense team made this argument most powerfully during the final session in the High Court on June 10, 2008 when she buttressed the defense's claim for provocation in the heat of passion with the following: "The various restrictions on their rights faced by Chinese spouses who marry over [to Taiwan] already constitute an a priori unjust social structure. But when Jia Xinmin used this kind of social structure to control a Chinese spouse's behavior, this was the first injustice." This argument unsettled the moral bases of immigration regulation while it broadened the scope of responsibility in immigrantrelated domestic abuse cases to encompass both the abuser and the government itself.

Perhaps recognizing the complexities of the case and the limitations of traditional legal thinking, the High Court initially simply upheld the lower-court decision and rejected both appeals. ${ }^{69}$ The ruling's language borrowed heavily from the prior decision, staying carefully within the legal parameters established by the district judges and rejecting both the heat of passion and impaired mental state arguments reintroduced by the defense. ${ }^{70}$ The court acknowledged Zhao's history of abuse and its long-term impact on her physical and psychological health, confirming in the process the legal system's preliminary recognition of battered woman's syndrome and the role it played in Zhao's fateful response to Jia's threats that morning. But the ruling eliminated the broader discussion of inequities inherent in cross-border marriages and the effects of harsher restrictions faced by Chinese spouses found in both the defense argument and the lower-court ruling, reducing the nuances of this analysis to a brief comment on Zhao's unwillingness to divorce Jia because doing so would make her ineligible for residency status and citizenship. In short, the High Court was unable to view the case as more than a murder trial; the judges could not integrate in a single legal framework both the devastating impact of long-term spousal violence and the intimate consequences of discriminatory immigration policies derived from longstanding political and military conflict across the Strait. Zhao, on the other hand, powerfully connected the two during the close of the final court session on June 10,2008, when she summed up her account of how she had suffered in their marriage by proclaiming, "[Jia] used me as an outlet for his anger and hatred toward the Communist Party!"

68. Rethinking Nationalism Through Intimate Relationships: Conflicts in CrossStraight Marriages, supra note 19, at 83-84.

69. Taipei Dist. Ct. Pub. Prosecutor v. Zhao Yanbing, (台北地方法院檢察署檢察官 v. 趙岩冰) (Taiwan High Ct., Crim. Div., June 24, 2008) (Taiwan).

70. Id. at 4,12 . 


\section{ACTIVIST CONUNDRUMS}

June 24, 2008, the day the High Court issued its ruling in Zhao Yanbing's case, coincided with the tenth anniversary of the passage of Taiwan's Domestic Violence Prevention Act. ${ }^{71}$ The various organizations directly or indirectly involved in the case organized a press conference to publicize the ruling, as they had after the District Court ruling the previous September and prior to the first High Court session in December 2007. These press conferences and the strategy sessions that preceded them exposed some of the same tensions that had pervaded the actual legal proceedings, especially the question of whether it was possible to reconcile the recognition of gendered oppression inherent in domestic violence with the broader political, economic, and social inequalities experienced by immigrant spouses, without simultaneously raising the specter of fraudulent immigration motives. In an effort to use the findings in Zhao's case to advance the larger cause of domestic violence prevention, a diverse group of activists struggled with how to forge connections between immigrant and local women on the basis of shared interests. ${ }^{72}$

The activists who held the press conferences represented a range of organizations devoted to domestic violence prevention, women's rights and feminist activism, judicial reform, and immigrant rights for foreign and Chinese spouses in Taiwan. Fearing a conservative ruling from the High Court, the group planning the December 2007 press conference decided to emphasize the gendered inequalities that produced domestic violence and downplay Zhao's immigrant status. The speakers at the conference were ordered so as to draw attention to the need for greater gender consciousness in responding to domestic violence. They situated Zhao's case in a local trajectory of domestic violence-inspired spousal murders beginning with the 1993 Deng Ruwen case that motivated the collective legal and social action culminating in the 1998 Domestic Violence Prevention Act. ${ }^{73}$ Subsequent speakers examined the biases in the public prosecutor's appeal, critiquing its stereotypes of deserving domestic violence victims and ignorance of the complexity and variability of spousal abuse. ${ }^{74}$ Only at the very end did two participants address Zhao's immigrant status and its effect on her plight, describing

71. Jiating Baoli Fangzhi Fa (家庭暴力防治法) [Domestic Violence Prevention Act] (promulgated by the Executive Yuan June 28, 1998, effective June 28, 1998) (Taiwan).

72. This section is based on my participation in both the planning sessions and the press conferences in December 2007 and June 2008.

73. Taiwan Banqiao Dist. Ct. Pub. Prosecutor v. Deng Ruwen (台潄板橋地方法院檢察署檢察官 v. 鄧如雯), (Banqiao Dist. Ct. Feb. 23, 1994).

74. See supra Part IV. 
the unequal treatment of Chinese and foreign spouses in Taiwan's immigration policy and the gradual emergence of alternative legal frameworks in other countries for adjudicating domestic violence and immigrant status.

The activist strategy of emphasizing domestic violence as a threat to all women and minimizing attention to the disparate treatment of immigrant women was not unreasonable given the conservatism of the High Court and general societal suspicion of migrant spouses. By downplaying the impact of Zhao's immigrant standing, however, the speakers were unable to show the specific valence of gender discrimination in domestic violence cases that involved Chinese wives. Entrenched patriarchy in the judicial system and stereotypical portrayals of domestic violence "victims" could also be read as critiques of perceived gender nonconformity among Mainland Chinese women. ${ }^{75}$ Because activists adopted a strategy of de-emphasizing Zhao's immigrant status, they were unable to link these gender inequities to a specific kind of immigration experience and to the anxieties that made Chinese immigrants particularly "unsympathetic" victims in the eyes of bureaucrats, many legal professionals, and society at large. ${ }^{76}$

This strategy also made it difficult for press conference participants to expose parallels in discriminatory demands operative in both domestic violence adjudication and immigration regulation. For instance, the public prosecutor's appeal questioned the extent and intensity of Zhao's experience of abuse because she and Jia slept in separate rooms and "did not interact morning and night" (bing fei chaoxi xiangchu), thereby reaffirming the importance of coresidence in supporting claims of intimate-partner violence. ${ }^{77}$ This emphasis on shared accommodations also permeated policies that identified "sham" marriages among cross-Strait couples on the basis of "lack of proof of co-

75. For example, recall the prosecutor's accusation that Zhao "flaunted herself in public" and sought help through protection orders rather than "meekly accepting her humiliation."

76. This is not to say that activists necessarily failed to recognize these linkages, but that they chose strategically not to articulate them publicly. The unsympathetic status of Chinese spouses also finds expression in stereotypical accusations that they are spies, have suspect moral character (because they might be moonlighting as sex workers), or are only interested in material gains that they can take back to China. See, e.g., Gu Yuzhen (顧玉珍), Taohua Wu Chunfeng: Zhongguo Xinniang Ye Xiang (桃花舞春風: 中國新娘葉香) [A Peach Blossom Dancing in the Spring Breeze: Chinese Bride Ye Xiang], in SHANG HAI Wo DE SHI ZUI QIN MI DE REN: JIATING BAOLI WEIJI YU YINYING (傷害我的是最親密的人: 家庭暴力危機與困境) [My Abuser is the Person I am Most Intimate With: Domestic Violence Crisis and Response] 61 (Gu Yuzhen ed., 2003).

77. Taiwan Taipei Difang Fayuan Jiancha Shu Jianchaguan Shangsu Shu (台北地方法院檢察署檢察官上訴書) [Taipei Dist. Ct. Pub. Prosecutor App.], at 2 (Nov. 14, 2007) (Taiwan). 
residence" (meiyou tongju de shishi), simultaneously establishing a model of authentic marriage based on shared daily existence that ignored the diversity of living arrangements in a highly mobile society such as Taiwan.78 Only by examining gendered violence and immigration together can one see the shared logics that animate evaluations of domestic violence victimization and the authenticity of cross-border marriages, and thus expose the double force of these discriminatory expectations when applied to immigrant wives faced with spousal abuse. These logics clearly work across institutional settings and discursive frameworks, linking judicial and bureaucratic domains in a shared institutional "matrix" of immigration regulation and gender discrimination. ${ }^{79}$

The press conference that followed the High Court ruling in June 2008 placed even greater emphasis on how the case contributed to the cause of domestic violence prevention in Taiwan. The conference began with a long, detailed statement by the lead female defense lawyer in which she drew direct parallels between Zhao and Deng Ruwen, whose case had also been argued (albeit less successfully) on the basis of selfdefense and impaired mental state, and the lawyer used the ruling in Zhao's case to show how judicial and legal awareness of domestic violence and battered women's syndrome had progressed in the intervening years. Although optimistic about how Zhao's ruling reflected greater understanding of spousal abuse, she nonetheless pointed to both courts' unwillingness to consider the heat of passion argument as evidence of need for improvement in this legal area.

In her statement to the press, the defense lawyer chose not to emphasize the inequity and hardship of immigration regulation, but focused instead on changing societal values that denounced the inhumanity at the heart of domestic violence and that, she argued, should be recognized as spawning the righteous anger foundational to a heat of passion argument. She simultaneously urged the prosecutor not to appeal the High Court decision and encouraged Zhao to appeal to the Supreme Court (zui gao fayuan) in the hope that it would recognize the validity of the heat of passion argument and, in doing so, further advance domestic violence protections by expanding the legal principles

78. Dalu Diqu Renmin zai Taiwan Diqu Yiqin Juliu Changqi Juliu huo Dingju Xuke Banfa (大陸地區人民在臺灣地區依親居留長期居留或定居許可辦法) [Permit Regulations for Kinship-Based, Extended, or Permanent Residence of Peoples of the Mainland Area in the Taiwan Area] (promulgated by the Ministry of the Interior [Immigration], Aug. 12, 2009, effective Aug. 12, 2009) arts. 14, 26, 33 (Taiwan).

79. David Jacobson, Multiculturalism, Gender, and Rights, in MIGRATIONS AND MoBILITIES: CitIZENShIP, BoRDERS, AND GENDER 304, 308 (Seyla Benhabib \& Judith Resnik eds., 2009). 
available to lawyers committed to the cause of combating domestic abuse.

The focus of the press conference shifted after the lawyer's presentation, however, and subsequent speakers from immigrant rights organizations spoke directly to the plight of Chinese spouses in Taiwan. They emphasized the isolation of immigrant women and their marginalized status, pointing to both their position as strangers in a strange land and the discriminatory effects of government policies. One speaker, who was married to a Chinese woman, called directly on Taiwanese husbands to care for and protect their wives in order to prevent the repeated tragedy of domestic violence. The other presenter underscored how existing policies created overwhelming obstacles to achieving secure status in Taiwan and granted too much power to the guarantor, typically the citizen-husband. Both speakers argued that the government should play a more prominent role in assisting immigrant spouses who suffer from domestic violence by considering legal reforms that would provide an acceptable path out of an abusive marriage. The moderator, representing the anti-domestic violence organization that had supported Zhao through the trials, summed up this argument by urging the press to stand in the shoes of new immigrants and investigate the inadequacies in current laws as part of encouraging the government to embark on a path of reform.

After much discussion during the planning meeting for the conference, the organizers agreed that Zhao should speak to the press herself as she desired. Zhao's initial commentary was brief and her voice quavered as she thanked all the parties involved, including the courts, for their support. Later, when a member of the press asked her about her plans for the future now that the trial was over, Zhao seemed to regain her strength and spoke at greater length about her experiences, adding important personal dimensions that fleshed out a narrative of shattered immigration dreams. In doing so, however, she also risked introducing questions about her immigration motives that undermined the sympathetic portrayal painstakingly created by the other participants. This tension culminated in Zhao's description of how Jia had lied to her about his life circumstances, and how as a Mainland Chinese citizen she had no way to verify the details until she moved to Taiwan (which she could only do after she married him). And by then it was too late: "using this marriage to immigrate, when I actually came from the other shore [other side of the Strait] to this shore, I . . really, my immigration dream truly was shattered."

Zhao's powerful statement not only conveyed the depth of her disappointment and suffering as an immigrant, but it also baldly acknowledged her "use" of marriage as a means of immigrating to 
Taiwan, affirming the kind of instrumentalism suspected by the High Court judges. The moderator quickly intervened at this point with the comment, "I think Yanbing's emotions are a little unstable right now," in an effort both to provide Zhao with an excuse to end her commentary and possibly to diminish its impact on the audience's perception of her marital motives. But Zhao ignored this opening and continued with her narrative about the abuse she had suffered at Jia's hands, interrupted on several occasions by the moderator who urged her to rest. Finally, the moderator simply stepped in and responded to the reporter's question about Zhao's future plans by pointing out how difficult it would be for Zhao both to remain in Taiwan and to return to China. At the same time, she also used this opportunity to reiterate the shared plight of local and immigrant women, both of whom faced obstacles to "returning home" in the wake of domestic violence. Once again she urged the press to put themselves in Zhao's position by considering how they would respond if they had a daughter who married an American and later faced domestic abuse as a powerless foreigner in a strange land.

Although overall the press conference underscored both the specificities of Zhao's experience as an immigrant wife and the features of spousal abuse shared by all women, it also situated the court rulings in a longer history of domestic violence in Taiwan that incorporated Zhao's suffering into a genealogy of domestic violence-spousal murder cases beginning with Deng Ruwen in 1993. The tension between these specific and general goals ran throughout the presentations and responses to audience questions, shaping decisions about what to say and what to leave out, and how to respond to potential flashpoints for conflict such as Zhao's portrayal of her marriage as a tool for facilitating immigration.

Ultimately, despite the risk of allowing Zhao to speak for herself, her commentary opened up the discussion to questions that exposed how little reporters knew about the reality of immigrant experience in Taiwan, including basic facts such as migrant spouses' inability to remain in the country following divorce if they did not win child custody or the use of separate laws to regulate Chinese and foreign spouses. Although the press conference stressed how these differences created a restrictive environment for all immigrant wives faced with domestic abuse, the articles published in its aftermath generally emphasized either the specifics of Zhao's situation or the legal significance of the self-defense ruling. The articles did not, however, make overt connections to the plight of local women who faced domestic violence, suggesting how difficult indeed it was to build bridges across the 
immigrant-citizen divide and mobilize immigrant women's suffering for the larger cause of domestic violence prevention in Taiwan.

\section{CONCLUDING THOUghtS}

When I last returned to Taiwan in the summer of 2011, I discovered that Zhao Yanbing was in jail serving her sentence of eighteen months. Although at the June 2008 press conference the lead defense lawyer had called for an appeal on Zhao's behalf, she later changed her position to ensure that the self-defense finding would stand as legal precedent. In the end, it was Zhao herself who pushed for the appeal in hopes of winning a suspended sentence or, at minimum, drawing out the process to delay deportation and a humiliating return to China. 80 The Supreme Court ruling was not only a setback for Zhao personally but also for the larger cause of legal redress in response to the spiral effects of domestic violence.

After sitting on the case for more than two years, the Supreme Court initially ruled in September 2010 by revoking the prior ruling and sending the case back to the High Court, arguing that the lower courts had not adequately investigated contradictions and gaps in the existing evidence. ${ }^{81}$ The Court stressed the excessive nature of Zhao's response to Jia's threat, providing an opening for the High Court to reconsider the broad self-defense finding issued at the district level. Not surprisingly, the High Court's new ruling in January 2011 found Zhao guilty of murder with a sentence of three years reduced to eighteen months. ${ }^{82}$

80. The Mainland Chinese press picked up the murder story from the Taiwan media and reprinted accounts appeared on the Internet, including photos of Zhao herself. See Dalu Peiou bu Kan Jiabao Shafu An: Yin Zhengdang Fangwei Huo Jianxing (大陆配偶不堪家暴杀夫案 因正当防卫获减刑) [Mainland Spouse Can't Bear Domestic Violence Spousal Murder Case: Receives Reduced Sentence Due to Self-Defense] HUAXIA JINGWEI NET (华夏经纬网) (Sept. 28, 2007), http://www.huaxia.com/tw/sdbd/sh/2007/00691192.html; Qi Qing Ke Min, Lupei Shafu Pan Yinianban Ding Yan (其情可悯 陆配杀夫制1年半定诫) [Sympathy for Her Plight: Mainland Spouse Declared Guilty, Sentenced to One and a Half Years] CHINA REV. NEwS (May 5, 2011), http://www.zhgpl.com/doc/1016/8/4/0/ $101684010 . \mathrm{html}$ ?coluid $=7 \& \mathrm{kindid}=0 \&$ docid $=101684010$. There is very little chance that Zhao will be allowed to stay in Taiwan after she serves her sentence, for current regulations explicitly exclude Chinese immigrants convicted of a serious crime from residency or citizenship eligibility. See Permit Regulations for Kinship-Based, Extended, or Permanent Residence of Peoples of the Mainland Area in the Taiwan Area, arts. 14, 26, 33.

81. Taipei Dist. Ct. Pub. Prosecutor v. Zhao Yanbing (台北地方法院檢察署檢察官 v. 趋岩冰) (Taiwan Sup. Ct., Crim. Div., Sept. 9, 2010).

82. Taipei Dist. Ct. Pub. Prosecutor v. Zhao Yanbing (台北地方法院檢察署檢察官 v. 趙岩冰), (Taiwan High Ct., Crim Div., Jan. 20, 2011). 
In reevaluating the evidence and Zhao's court testimony, the new ruling divided her actions into two stages: one, hitting Jia with the hammer in response to his threatened attack with the knife, and two, stabbing him to death after she had already knocked him unconscious. The judges defined the first stage as a defensive response to Jia's threat, but found the second stage to constitute murder, thus vitiating the original self-defense ruling that viewed both acts as part of the same sequence of action (and in so doing, at least partially recognized how battered women's syndrome shaped perceptions of threat). Discussion of Zhao's origins in China and the tenor of her relationship with Jia was reduced to background information, and analysis of her vulnerability as an immigrant spouse and how her immigrant status exacerbated the couple's marital conflicts was moved to the sentencing section where it supported the Court's reduction of her sentence to eighteen months (the original sentence issued by the district court). After the defense appealed again to the Supreme Court, the Supreme Court rejected the appeal, upholding the new High Court ruling and sending Zhao to jail to serve her time. ${ }^{83}$

Zhao's case speaks to persistent tensions between the legal system's commitment to protecting women abused by their spouses (or other family members) and the immigration bureaucracy's abiding goal of blocking the entry of or deporting immigrant spouses with suspect marital motivations or preventing them from acquiring citizenship when detached from a kinship bond to a citizen. These two agendas animate different legal and bureaucratic apparatuses that mobilize investigative, protective, and disciplinary procedures with disparate, and at times competing, ethical foundations. When immigrant women experience domestic violence, they bring these two domains into intimate interaction and expose the fundamental contradictions in their aims and methods. ${ }^{84}$

Requirements for protection orders versus procedures for obtaining legal residency, expectations of shared residence versus constant exposure to abuse, and the agendas of immigration bureaucrats as opposed to social workers and legal professionals together create a double authenticity bind that requires immigrant spouses to prove the "veracity" of both their abuse and their marriage. Concerns expressed at all levels of the court system about whether Zhao Yanbing fulfilled her wifely duties as defined by a caretaking model of authentic marriage testify to an abiding judicial emphasis on evaluating immigrant spouses'

83. Taipei Dist. Ct. Pub. Prosecutor v. Zhao Yanbing (台北地方法院檢察署檢察官 v. 趋岩冰) (Taiwan Sup. Ct., Crim. Div., May 5, 2011).

84. See Gu, supra note 76, at 77-79. 
abuse claims in terms at once gendered and nationalist. ${ }^{85}$ Expanding battered immigrant spouses' ability to obtain legal residency independent of their citizen-partner potentially introduces a window for misuse of immigration channels, but such a risk is outweighed by the difficulties of successfully deploying domestic violence exceptions and by the ethical imperative to offer concrete protections for those who require them. 86

Through the legal progression of cases such as that of Zhao Yanbing, we see that immigrant women's abuse can potentially be mobilized to generate advances in law and protective services that benefit all women in Taiwan, regardless of their citizenship status. But activating awareness of shared interests is another matter, and such efforts often founder on the divisive terrain where domestic violence prevention meets immigration regulation. Authenticity concerns not only dominate bureaucratic and legal domains; they also infiltrate public opinion to such an extent that activists who otherwise acknowledge their debilitating effects on immigrant women nonetheless hesitate to discuss these contradictions openly for fear of undermining efforts to advance recognition of the complexity and scope of intimate partner violence. Committed responses to the specific kind of immigration failure produced when cross-border marriages lead to domestic violence demand collaborative work across legal, bureaucratic, social work, and activist sectors. The first steps toward preventing this violence require replacing authenticity concerns with humanitarian commitments and recognizing the complexity of immigration motivations and the diversity of intimate relationships created in an increasingly mobile world.

85. This judicial emphasis, even at the District Court level, not only reinforced traditional gender norms in cross-border marriages, but it also contributed to a "blame the victim" mentality instead of holding the government-husband responsible for excessive control over immigrant wives. I thank Chao-ju Chen for helping me make this connection.

86. See generally Chen, supra note $32 ; \mathrm{Gu}$, supra note 76 . 
